University of Florida Levin College of Law

UF Law Scholarship Repository

UF Law Faculty Publications

Faculty Scholarship

2001

Racial Profiling: A Status Report of the Legal, Legislative, and Empirical Literature

Katheryn Russell-Brown

University of Florida Levin College of Law, russellbrown@law.ufl.edu

Follow this and additional works at: https://scholarship.law.ufl.edu/facultypub

Part of the Civil Rights and Discrimination Commons, and the Law Enforcement and Corrections

Commons

Recommended Citation

Katheryn Russell-Brown, Racial Profiling: A Status Report of the Legal, Legislative, and Empirical Literature, 3 Rutgers Race \& L. Rev. 61 (2001), available at http://scholarship.law.ufl.edu/facultypub/216

This Article is brought to you for free and open access by the Faculty Scholarship at UF Law Scholarship Repository. It has been accepted for inclusion in UF Law Faculty Publications by an authorized administrator of UF Law Scholarship Repository. For more information, please contact kaleita@law.ufl.edu. 


\title{
RACIAL PROFILING: A STATUS REPORT OF THE LEGAL, LEGISLATIVE, AND EMPIRICAL LITERATURE
}

\author{
Katheryn K. Russell*
}

\section{INTRODUCTION}

The classic Dickensian paradox is appropriate to describe the state of racial profiling research. It is the best of times. It is the worst of times. The issue of racial profiling has surged to the forefront of the nation's political and public consciousness. It has become the topic of interest for civil libertarians. Racial profiling is hot. It has become a hot topic for civil libertarians (who are opposed to it) ${ }^{1}$, police (who say it is either "good policing" 2 or occurs infrequently) ${ }^{3}$, legislators (who say it

* Associate Professor, University of Maryland, Department of Criminology \& Criminal Justice Department. B.A., University of California, Berkeley (1983); J.D., Hastings Law School (1986); Ph.D., University of Maryland (1992). The Author thanks Kenneth Adebonojo for the invitation to participate in this symposium. The Author can be contacted at the Department of Criminology \& Criminal Justice, 2220 LeFrak Hall, University of Maryland, College Park, MD 20742, or via e-mail at krussell@crim.umd.edu.

1. See David A. Harris, Driving While Black: Racial Profiling On Our Nation's Highways, available at http://www.aclu.org/profiling/report/index.html (reporting a detailed summary of profiling, including an overview and analysis of relevant U.S. Supreme Court cases, and a catalog of national newspaper stories on profiling incidents) (June 1999).

2. See, e.g., Michael Fletcher, Driven To Extremes: Black Men Take Steps to Avoid Police Stops WAst. Post, March 29, 1996, at A22 (citing comment by Lt. Ernest Leatherbury, spokesman for Maryland State Police, that disproportionate stops of Black motorists are "an unfortunate by-product of sound police practices"). Within police ranks, however, there is a split opinion as to the degree to which racial profiling exists and what should be done about it. For example, notably, the National Organization of Black Law Enforcement Officers (NOBLE) has opposed the practice and supported legislation to track police stops, available at http://www.noblenatl.org/ resolu.html.

Moreover, an Illinois civil rights lawsuit filed by five White Highland Park police officers offers a typical insight into their department. The officers allege that the practice of racial profiling is rampant in their department:

The racial profiling policy was direct, but unwritten, and known as the 'NUT ordinance, meaning that no 'Niggers' were allowed 'Up Town'.... In addition, [officers were] encouraged to engage in 'of- 
should be studied) ${ }^{4}$ and the public (who says it is prevalent and not an appropriate police response to crime). ${ }^{5}$

In recent years, there have been several widely-publicized cases in which racial profiling became police brutality. ${ }^{6}$ As well, there have been scores of famous Black men who have offered their personal accounts as victims of racial profiling.?

fensive talk' including racial and ethnic slurs, epithets and jokes, which created an atmosphere and formed attitudes demeaning to Hispanics and African-Americans as a class, which in turn led to, and triggered race-based conduct during police encounters on the street.

Rodney Watt v. City of Highland Park, No. 98C8123 slip op. at _ (N.D. Ill. 2000).

3. See, e.g., Robert L. Jackson, Push Against Bias in Traffic Stops Arrested, Los ANGeles Times, June 1, 1998, at A5 (discussing the National Association of Police Organizations (NAPO) opposition to data collection on racial profiling because there is "no pressing need or justification").

4. See, e.g., Traffic Stops Statistics Study Act of 2000, H.R. 1443, 106th Cong. $\S 2$ (2000).

5. See, e.g., Gallup Poll, Racial Profiling is Seen as Widespread, Particularly Among Young Black Men, (Dec. 9, 1999), available at http:// www.gallup.com/pull/releases/pr991209.asp. The poll found that $59 \%$ of the adults surveyed (Black and White) believe that profiling is a common police practice. Fifty-six percent of Whites said profiling is widespread, while $77 \%$ of Blacks said it is widespread. Further, $81 \%$ of those polled indicated that they disapprove of profiling. Additionally, the survey found that $42 \%$ of the Blacks polled said they had been subjected to racial profiling, compared with $6 \%$ of Whites. Also noteworthy, approximately $75 \%$ of the young Black men (ages 18-34) who were surveyed said they had experienced a raciallymotivated traffic stop.

6. In February 1999, Amadou Diallo, a Guinean immigrant, was gunned down by four New York City police officers. See Michael Grunwald, Unarmed Immigrant Killed by N.Y. Police Is Mourned, WASH. PosT, Feb. 13, 1999 , at A3. The undercover officers, who were looking for a rape suspect, spotted Diallo in his apartment vestibule. See Kevin Flynn, Shooting in the Bronx: The Overview; Revisiting a Killing: Many Details, but a Mystery Remains, N.Y. TIMEs, Feb. 14, 1999, at 37. Diallo was shot after police mistook his wallet for a gun. See id. In March 2000, the officers were acquitted of any criminal wrongdoing. See Dan Rather, The Diallo Verdict and the Fact of Justice, House CHRONICAL, Mar. 5, 2000, at 6. Days following the acquittal of the Diallo officers, an undercover New York officer shot and killed Patrick Dorismond, a Jamaican immigrant. Police approached Dorismond about a drug sale. See CHI. TriB., July 28, 2000, at 8N. Dorismond was killed in the scuffle that ensued.

7. A short list of names includes Marcus Allen, LeVar Burton, Calvin Butts, Johnnie Cochran, Miles Davis, Christopher Darden, Will Smith, Wesley Snipes, Blair Underwood, and Cornel West. See, e.g., KatheryN K. 
All of these have helped to propel the issue onto the nation's front burner. The varied responses to racial profiling indicate the range of groups affected by and concerned about the practice. Notably, this includes former President Bill Clinton, who shared his belief that racial profiling is a national problem. ${ }^{8}$

The issue of racial profiling has evoked a wide range of policy responses, including legislation, political commentary, community protests, and empirical study. The groundswell of activity around the topic invites a preliminary assessment and critique of the state of the existing literature on racial profiling.

This article, divided into four parts, provides a status report on racial profiling research. The first section discusses and analyzes how the term "racial profiling" has been defined. The second part categorizes the legislation, federal and state, introduced in response to the problem of racial targeting. This section also provides an overview of the empirical research on racial profiling. The third part includes a critique and assessment of the existing literature and offers a road map for future legislation and research on racial profiling.

\section{DEFINING TERMS: WHAT'S IN THE KITCHEN SINK?}

One goal of those who seek to place an issue on the political agenda, is to find a label or acronym that encapsulates its ma-

Russelal, The Color of Crime: Racial Hoaxes, White fear, Black Protectionism, Police Harassment and Other Macroaggressions 37 (1998).

8 . Clinton stated that racial profiling is a "morally indefensible [and] deeply corrosive practice." Randall Kennedy, Suspect Policy, THE NEw REPUBLIC, Sept. 13 \& 20,1999, at 31. Suggesting as well that the police shooting death of Amadou Diallo was the result of racial profiling, Clinton commented, "I know that most people in America of all races believe that if it had been a young white man in an all-white neighborhood, it probably wouldn't have happened." Race a Factor in Diallo Case, Clinton Says, WAsH. Post, Mar. 5, 2000, at A8. On August 14, 2000, during his last presidential speech at a Democratic National Convention, Clinton referred to racial profiling as a form of bigotry his administration has opposed. "America is . . More Secure and More Free" (Excerpt of President Clinton's Address) Wash. Post, Aug. 15, 2000, at A13 (Associated Press), available at http:// www.washingtonpost.com/wp-dyn/articles/A27116-2000Aug14.html. 
jor themes. A label or acronym so interesting that it will spark interest, debate, and ultimately change. Driving While Black ("DWB"), another name for racial profiling, is an example of this.

Racial profiling is not a new phenomenon. ${ }^{9}$ However, as a social problem, it gained new legs once DWB entered the public $^{10}$ and legal ${ }^{11}$ lexicon. The term "racial profiling" oft-times refers to a practice employed by law enforcement officials. Specifically, those practices which single out Blacks for traffic stops and questioning. ${ }^{12}$ However, it is worthwhile to examine some of the other ways the term is used and the policy implications of these uses.

9. See, e.g., Tracey Maclin, Terry and Race: Terry v. Ohio's Fourth Amendment Legacy: Black Men and Police Discretion, 72 ST. JoHN's L. REv. 1271,1272 (1998) ("When one examines the history and modern exercise of police 'stop and frisk' practices, the old adage 'the more things change the more they stay the same,' aptly describes the experiences of many Black men when confronted by police officers.") Id.

10. See, e.g., supra note 3.

11. See, e.g., United States v. Montero-Camorga, 208 F.3d 1122, 1132 (9th Cir. 1999). ("[E]xperiences on the part of African Americans have given rise to the better known term, 'Driving While Black'"); see also United States v. Leviner, 31 F. Supp. 2d 23, 33 (1998) ("Motor vehicle offenses, in particular, raise deep concerns about racial disparity. Studies from a number of scholars and articles in the popular literature have focused on the fact that African-American motorists are stopped and prosecuted for traffic stops, more than any other citizens"); see, e.g., Washington v. Lambert, 98 F.3d 1181, 1188 (9th Cir. 1996) ("There's a moving violation that many AfricanAmericans know as D.W.B.: Driving While Black. These encounters are humiliating, damaging to the detainees' self-esteem, and reinforce the reality that racism and intolerance are for many African-Americans a regular part of their daily lives".)

12. DWB has also been used to refer to the racial profiling of other minorities. See, e.g., Montero-Camorga, 208 F.3d at 1122 (involving a challenge to the U.S. Border Patrol's practice of using Hispanic ethnicity as a factor in making vehicle stops); Leonel Sanchez, Latinos Protest Ethnic Profiling: Complaints Mount Against Immigration and Police Officers, SAN D1EGO UNION-TRIBUNE, July 24, 2000, at A1 (detailing frequency with which Latinos are stopped near the U.S.-Mexico border). See also LESLIE Marmon Silko, Yellow Woman and a Beauty of the Spirit: Essays on Native AMERICAN LIFE TODAY, 107-23 (1996) (describing the racial profiling of American Indians). 


\section{A. Searching for Territory}

"Racial profiling" has been used to describe a wide range of activity. In some instances it is used as an all-encompassing label, one which describes everything and nothing. For example, when the term is used to describe any interaction between a person of color and the police. Such a sweeping use makes racial profiling easy to dismiss as proof of Black racial paranoia. Further, this broad definition leaves little room to address the specific, acute problem of racially-targeted motorist stops. The likelihood of finding a solution is greater where the harm is precisely identified and defined.

An assessment of how "racial profiling" is defined raises three central questions. First, does it refer to the practice in which police use race as one factor to determine whether to stop a motorist? Or, does it refer only to the practice in which police use race as the sole basis for a motorist stop? Second, to whom does the term apply? Does it apply only to law enforcement officers? Or, does it apply to any social institution or business which singles out Blacks (or other minorities) for harsher, less-favorable treatment ${ }^{13}$ Third, assuming that the term is limited to police activity, to which types does it apply? For example, does it apply to both vehicle stops and street stops. ${ }^{14}$

As to the first question, there has been discussion and debate about the degree to which racial profiling implicates race. ${ }^{15}$ On this issue, the U.S. Supreme Court has offered dimmers rather than fog lights. Specifically, the Court has clearly stated that law enforcement officials may use race as one of several factors in deciding whether to stop and question a sus-

13. For example, in the last few years there have been several successful lawsuits against corporations that have engaged anti-Black racial discrimination. See, e.g., LaRouche v. Denny's Inc., 62 F. Supp. 2d 1375; 1999 U.S. Dist. LEXIS 13063; Charity v. Denny's Inc., 1999 U.S. Dist. LEXIS 11462; Clemmons v. Domino's Pizza, Inc., 1996 U.S. Dist. LEXIS 21363.

14. See, e.g., Terry v. Ohio, 392 U.S. 1 (1968).

15. Although much of the public discussion on racial profiling involves motorist stops, racial profiling stops occur in various forms. See, e.g., Government Accounting Office (Mar. 2000), U.S. Customs Service: Better Targeting of Airline Passengers for Personal Searches Could Produce Better Results, available at http://www.gao.gov/new.items/gg00038.pdf. 
pect. ${ }^{16}$ As well, the Court has indicated that race should not be the sole criterium for initiating a police stop. On balance, the Court has apparently concluded that ensuring police discretion is more highly valued than determining the role that race plays in an officer's calculus to initiate a traffic stop. ${ }^{17}$ The Supreme Court has bypassed several opportunities to squarely address the use of race by law enforcement officers. ${ }^{18}$ The result? A pell-mell approach to police, race, and racial profiling. 19

The second query reflects the increasingly colloquial use of "racial profiling". When invoked generically, the term can include any and all race-based encounters-those initiated by private citizens (e.g., department store employees who follow Black customers around the store ${ }^{20}$ ) as well as those instigated

16. Not all commentators agree with this view. Randall Kennedy, for example, argues that any consideration of race in a police officer's decision to stop a citizen is impermissible. See Kennedy, supra note 9, at 31. But see Anthony Thompson, Stopping the Usual Suspects: Race and the Fourth Amendment 74 N.Y.U. L. REv. 956, 1005 (1999) (indicating that the use of race is a tough but workable proxy for suspicion, and may be acceptable "in certain circumstances").

17. It could be reasonably argued that having trial court judges determine whether a stop was racially-motivated would do little to stem the flow of racial profiling incidents. It simply shifts the analysis of whether race was properly relied upon, away from the police, towards the judge. As Anthony Thompson notes, " $[\mathrm{M}]$ any judges share the same cognitive and cultural limitations as the police officers testifying before them[.]" See Thompson supra note 16, ar 1007 (citations omitted).

18. For example, in Whren v. United States, 517 U.S. 806, 813 (1996), a unanimous Supreme Court expressly avoided the race issue.

19. There have been a number of thoughtful law review articles that have evaluated the Supreme Court's treatment of race and the Fourth Amendment. See Angela J. Davis, Race, Cops, and Traffic Stops, 51 U. Mrami L. REv. 425, 442 (1997) (concluding that the Supreme Court's refusal to provide redress for race-based pretextual traffic stops "leave[s] African-Americans and other people of color without a clear and effective remedy for this discriminatory treatment"); David A. Harris, Car Wars: The Fourth Amendment's Death on the Highway, 66 Geo. WaSh. L. Rev. 556, 556 (1998) (describing the Supreme Court's Fourth Amendment jurisprudence as "tattered and full of holes as a beggar's winter coat"); see also Thompson, supra note 17, at 962 (showing that the Supreme Court's Fourth Amendment analysis ostensibly offers a raceless jurisprudence in Terry, Whren, and the cases between them (emphasis added)).

20. See, e.g., Alonzo Jackson v. Eddie Bauer, 96-CV-54 (1997). This case involved Jackson, a young, Black man, who was suspected of shoplifting a 
by the police. ${ }^{21}$ Used in such a common manner, the term could refer to any encounter Blacks have with a person or institution that is not identifiably Black. ${ }^{22}$

The third question, regarding which type of police activity racial profiling applies to, is fairly straightforward. A strong case can be made that any time police use race to make a stop, it constitutes racial profiling. ${ }^{23}$

As the above discussion amply illustrates, racial profiling means different things to different people. When broadly defined, however, the problematic nature of racially-motivated

shirt from an Eddie Bauer outlet store. The store's security guard, an undercover police officer, would not let Jackson leave until he removed the shirt he was wearing. Jackson and his peers filed a successful civil suit. They were awarded a total of $\$ 1$ million. See id.

21. Given that Blackness has become synonymous with criminality, it is predictable that racial profiling is sometimes used to indicate a negative encounter driven by the perception of Black deviance. See, e.g., Russell, supra note 8 , at 3 (discussing "criminalblackman" as a term which denotes the presumed association between Blackness and deviance).

22. See, e.g., Kenneth Meeks, Driving While Black: Highways, Shopping Malls, Taxicabs, Smewalks 63-160 (2000) (Details variety of ways in which African-Americans are profiled, including "Riding the Train While Black", "Shopping in a Group While Black", "Shopping Alone While Black" and "Flying While Black". Meeks also traces the history of racial profiling to the slave codes, a time during which, "court officials permitted constables and ordinary citizens the right to " take up' all black persons seen 'gadding abroad' without their master's permission." Thus, racial profiling "transcends law enforcement and includes everyone"); Katheryn K. Russell, "Driving While Black": Corollary Phenomena and Collateral Consequences, XL B.C. L. REv. 717, 721-23 (1999) (citing racial profiling cases involving, "Walking While Black", "Idling While Black" and "Breathing While Black").

As noted by the above examples, racial profiling presents a problem at both ends of the spectrum. At one end, it may be the result of "hyper-visibility." That is, Blacks are more likely to be observed and singled out for traffic stops and questioning. At the other end, there is the problem of "hyper-invisibility" as well. An example of this is "taxicab discrimination". E.g., Loren Page Ambinder, Dispelling the Myth of Rationality: Racial Discrimination in Taxicab Service and the Efficacy of Litigation Under 42 U.S.C. \$ 1981, 64 GEO. WASH. L. Rev., 342, 343 (1996). A 1999 taxicab incident involving actor Danny Glover sheds light on this issue. See Montel Williams, Danny Glover Says Cabbies Discriminated Against Him, N.Y. TImes, Nov. 4, 1999 , at B8.

23. This would include, street stops, as detailed in Terry, 392 U.S. at 4. In fact, the Fourth Amendment analyses make no such distinction. See Harris, supra note 20 at 556; Thompson, supra note 17, at 962. 
traffic stops is easily minimized. Racial profiling in traffic stops-a burgeoning social issue ${ }^{24}$-mandates an analytical spotlight all its own. Thus, for purposes of this Article, "racial profiling" is used to refer to the use of race as either the sole factor, or one of several factors, by a law enforcement official, in a decision to stop, search, or arrest a motorist.

\section{WHAT WE KNOW: OVERVIEW OF LEGISLATION \& RESEARCH}

In recent years, articles and stories on race and traffic stops have become commonplace in mainstream newspaper, television, and radio reports. Concomitantly, there has been a flurry of legislation and police department activity at the federal, state, and local levels. ${ }^{25}$ Interestingly, however, the level of media and legislative attention has not been met with a comparable level of social science investigation into racial profiling. This section provides an overview of the existing legislation and empirical research on racial targeting.

\section{A. Law \& Legislation}

The Federal Bill Since 1997, the Traffic Stops Statistics Study Act has been, in one form or another, on the U.S. Congressional burner. ${ }^{26}$ Representative John Conyers (D-Mich) introduced the bill to both study and stem the problem of racial profiling. The bill was drafted in direct response to charges that claims of racial profiling were "anecdotal"- and, therefore, empirically suspect. ${ }^{27}$ As drafted, the Conyer's bill

24. For example, the "Redeem the Dream" march held on August 26, 2000 , was organized to protest racial profiling in various forms, including the one by law enforcement. See, e.g., Arthur Santana, Activists Seek Penalties to Halt Racial Profiling; King, Shaprton Meet Reno Before D.C. Rally, Wash. Post, Aug. 26, 2000, at B01; Race Relations: D.C. Rally Protests Racial Profiling, Facts on File World News Digest, Aug. 26, 2000, at 646, F2.

25. See infra notes $27,29,33-35$, and 37 .

26. See H.R. 1443, 106th Cong. (1999); see H.R. 118, 105th Cong. (1997).

27. In the notes following the initial draft of the bill, Conyer's remarks, "There are virtually no African-American males-including Congressmen, actors, athletes and office workers who have not been stopped at one time or another for an alleged traffic violation, then harassed with questions and 
would mandate the collection of detailed traffic stop data, including:

* identifying characteristics of the persons stopped, including race, ethnicity, age, and gender;

* traffic infraction alleged to have been committed;

* number of people in the stopped vehicle;

* whether immigration status was questioned;

* whether a search was conducted (if so, whether consent was requested);

* rationale for the search (e.g., alleged criminal behavior);

* whether a "warning or citation" was issued;

* whether an arrest was made; and

* duration of the traffic stop. ${ }^{28}$

The Conyer's bill directs the Attorney General to collect these data and to publish an annual summary of the findings. ${ }^{29}$ The bill represents the dominant piece of legislation offered in response to the racial profiling problem. Though it has yet to pass Congress, the bill has served as a model for companion legislation and activity in several jurisdictions. ${ }^{30}$ In fact, states and municipalities have responded to concerns about "racial

searches. They may not receive tickets but they do receive humiliation and more reason to distrust the justice system." (On file with Author).

28. H.R. $1443 \S 2$. This bill mandates data collection from a nationwide sample of jurisdictions, including those identified in the initial analysis. See id. Notably, in its first version (1997), the bill required that data be gathered from each stop, rather than a sample of jurisdictions. See id. H.R. 118.

29. See H.R. $1443 \S 2$.

30. As well, federal law enforcement agencies have been faced with racial monitoring. See, e.g., Memorandum on Fairness in Law Enforcement, 35 Weekly Comp. Pres. Doc. 1067 (June 9, 1999). President Clinton issued a memorandum instructing the Attorney General to design and institute a system which would gather data on race and gender for law enforcement activities. See id. This directive includes the Drug Enforcement Administration, the Immigration and Naturalization Service, and the U.S. Customs Service. For the full text of the U.S. Customs' report (Mar. 2000), see General Accounting Office, GAO/GGO-00-38, U.S. Customs Service: Better Targeting of Airline Passengers for Personal Searches Could Produce Better Results. available at http://www.goa.gov/new.items/ggooo38.pdf. (Mar. 2000). 
profiling" in a variety of ways; these include state and local action as well as police department-initiated action. ${ }^{31}$

State-Level Legislation To date, more than a dozen jurisdictions have considered legislation to address the problem of racial profiling. Several have drafted, ${ }^{32}$ and in some instances passed, their own version of the Traffic Stops Statistics Study Act. ${ }^{33}$ Connecticut, ${ }^{34}$ North Carolina, ${ }^{35}$ and Maryland are three states that have enacted racial profiling bills. Notably, states with Democratic and Republican governors have adopted racial profiling related legislation.

LOCAL ACTION several jurisdictions have begun to collect race data for traffic stops without the enactment of state legislation. Among these locales are San Diego, San Jose, and Oakland, California; ${ }^{36}$ Houston; and Montgomery County, Maryland. ${ }^{37}$

31. The impetus for and type of traffic stop data collection varies across jurisdictions. Some have been motivated to consider and/or pass legislation as the result of a high-profile incident of "racial profiling", for example, California and Maryland. Others state have responded by undergoing a detailed assessment of the nature and degree of the problem. See, e.g., NEw JERSEY Department of LaW and Public Safety, Interim Report of the State Police Review Team Regarding Allegations of Racial Profiling, available at http:/ /www.stat.nj.us/lps/intm 419.pdf hereinafter [New Jersey Report] (Apr. 20, 1999).

32. These states include Arkansas, California, Florida, Illinois, Maryland, Massachusetts, Connecticut, North Carolina, Ohio, Oklahoma, Pennsylvania, Rhode Island, and South Carolina. See General Accounting Office, GAO/GGO-00-41. Racial Profiling: Limited Data Available on Motorist Stops 48-49 (Mar. 13, 2000) hereinafter [GAO Report].

33. See id.

34. See Sub. S. 1282, 1999 Gen. Assem., Jan. Sess. 1999 (Conn. 1999). Bill became law in June 1999. See an Act Concerning Traffic Stops Statistics, 1999 Conn. Acts 198 (1999).

35. See S. 76, 1999 Gen. Assem., Sess. 1999 (N.C. 1999). See Act of Apr. 22, 1999 N.S. Sess. Laws 26, N.C. Gen. Stat. \$ 114. The bill became law in April 1999 (Session Law 1999-26).

36. The California version of the Traffic Stops Statistics Act, A.B. 1264, passed in the state legislature but was ultimately vetoed by the Governor.

37. In the fall of 2000 , Montgomery County, Maryland initiated data collection data on traffic stops. In January 2000 , the county entered into an agreement with the U.S. Justice Department. Per the agreement, county police will collect traffic stop data in 12 fields, including driver's race, age, gender, county residency, vehicle code violation, and date of stop. Police enter data into a pocket personal computer. The process does not allow for the 
OTHER ACtrons Lawsuits challenging racial profiling have also affected how various jurisdictions address the problem. Cases have been filed on a variety of constitutional (Due Process and Equal Protection) and legislative (Civil Rights Act, Title VI, Omnibus Crime Control and Safe Streets Act) grounds. Legal redress has been sought across the country, including Oklahoma, New Jersey, Maryland, Illinois, Florida, Pennsylvania, and Colorado. ${ }^{38}$

\section{B. The Empirical Literature}

There are less than one-half dozen studies that assess and analyze the incidence and nature of racial profiling. ${ }^{39}$ This is in marked contrast to the swirl of legislative activity on racial targeting of motorists. Though there is clearly movement in terms of implementing police tracking procedures, the discussion below establishes that further research is necessary. What follows is an overview of four published articles on racial profiling studies. ${ }^{40}$

MARYLAND STUDY In the late 1990s, John Lamberth and his colleagues compared the racial distribution of motorists traveling on an interstate highway with the race of those motorists stopped on the highway by state troopers. ${ }^{41}$ The study

identification of particular officers. Montgomery police are assigned to "subgroups" (6-8 officers each) and data are only available at the subgroup level. Montgomery County Department of Police, Data Collection Protocol \& Summary of the Memorandum of Agreement Between the United States Department of Justice, Montgomery County, Montgomery County Department of Police, and the Fraternal Order of Police, Montgomery County Lodge 35, Inc. (2000), available at http://www.usdoj.gov/crt/Pubs/mcagrmt.htm.

38. See, e.g., Harris, Driving While Black 16-21 supra note 1. 2000).

39. General Accounting Office (report on racial profiling) 24-33 (Mar.

40. In March 2000, the Government Accounting Office published a report on racial profiling. This report references and reviews five quantitative studies of racial targeting by police. Four of these are discussed in this Article. A 1994 unpublished study by John Lamberth, "Revised Statistical Analysis of the Incidence of Police Stops and Arrests of Black Drivers/Travelers on the New Jersey Turnpike Between Exits or Interchanges 1 and 3 From 1988 Through 1994," is not discussed in this Article. GAO Report, at 24-33.

41. John Lamberth, Ph.D., American Civil Liberities Union Freedom Network, http://aclu.org.court/lamberth. html. (1996). 
is divided into two parts. ${ }^{42}$ The first part of the study was based upon a moving survey by researchers to determine the racial characteristics of highway motorists. ${ }^{43}$ As designed, the study provided data on the race of motorists and the race of motorists traveling over the speed limit. ${ }^{44}$ The survey estimated that there were more than 5,700 cars and identified the race in $97 \%$ of those cases. ${ }^{45}$ Lamberth and his colleagues found that $76 \%$ of the drivers were White, and $17 \%$ were African-American. ${ }^{46}$ Of those motorists observed violating traffic laws (e.g., speeding), $75 \%$ were White and $18 \%$ were AfricanAmerican.

The second part reviews the law enforcement records for the Maryland State Police. ${ }^{47}$ These data cover stops conducted between May and September 1997. ${ }^{48}$ During this period, the police made 11,823 vehicle stops. ${ }^{49}$ Sixty-four percent were White clrivers, $29 \%$ were African-American, and $2 \%$ were Hispanic. ${ }^{50}$ Lamberth also reviewed Maryland State Police data on those vehicles that were subject to a police search between January 1995 and September 1997.51 He found a reverse racial pattern; $71 \%$ of the motorists were AfricanAmerican, while $21 \%$ were White, and $2 \%$ were Hispanic. ${ }^{52}$

Based upon these findings, Lamberth concluded that African American motorists violate interstate traffic laws at a rate proportionate with their rate in the interstate driving population. ${ }^{53}$ However, African-Americans are stopped at almost two times their rate of travel and are more than four times as likely to have their vehicles searched. ${ }^{54}$

\footnotetext{
42. See id.

43. See id. at 27.

44. See id.

45. See id. at 27.

46. See id. at $27-28$.

47. See id. at 28.

48. See id. This includes data for Baltimore, Cecil and Hartford counties.

49. See id. at 28.

50. See id.

51. See id.

52. Data based upon searches carried out between January 1995 and September 1997 (in and outside the Interstate-95 corridor).

53. See id.

54. See id.
} 
Florida Study In this study, David Harris analyzes videotaped motorist stops (gathered over a 3-year period) along a section of the Interstate 95 corridor in Volusia County, Florida. ${ }^{55}$ The videotape data shows more than 1,100 vehicle stops. $^{56}$ Of these stops, $70 \%$ were African-American or Hispanic motorists. ${ }^{57}$ Approximately one-half of the cars that were pulled over were searched. ${ }^{58}$ Eighty percent of the cars searched had an African-American or Hispanic motorist. ${ }^{59}$ In addition, Harris found that the duration of the stops for minority motorists was double the time for White motorists. ${ }^{60}$ Notably, only nine of the motorists who were stopped (out of 1,100 total), received tickets. ${ }^{61}$

Harris then compared these data with population statistics. ${ }^{62}$ He found that African-Americans comprised less than $12 \%$ of the driving age population and approximately $15 \%$ of the driving traffic offenders in the state. ${ }^{63}$ Overall, Harris concludes that Black motorists are subject to vehicle stops at a raciallydisproportionate rate. ${ }^{64}$

Philadelphia AClU Monitoring Report This report analyzes the racial characteristics of motorists who were

55. David Harris, Driving While Black and All Other Traffic Offenses: The Supreme Court and Pretextual Traffic Stops, 87 J. CRIM. L. \& CRIMINOLOGX 544, 561-63 (1997).

56 . Vehicles were stopped for a range of reasons, including swerving, excessive speed, improper license tags, and failure to use proper signals. See id.

57. See id. at 562.

58. See id.

59. See id.

60. See id.

61. See id.

62. See id.

63. See id. Harris' study also includes data on traffic stops and searches by Maryland State Police (between January 1995 and June 1996). See id. at 563-66. These data indicate that out of 732 motorists who were pulled over by state troopers, $75 \%$ were African-American and $5 \%$ were Hispanic. See $i d$. at 566. Harris, however, does not provide any information on the percentage of minority motorists traveling on the interstate or the percentage who violate traffic laws.

64. See id. at 563, 582 . 
stopped in several Philadelphia police districts in 1997.65 In some instances, data for motorist and pedestrian stops are combined. ${ }^{66}$ The results indicate that where data on motorists race were available, minorities were disproportionately overrepresented. ${ }^{67}$ Specifically, minorities were more likely to be subject to stops that were later judged by a court to be baseless. ${ }^{6}$

New Jersey Attorney General's Interim Report This study reviews New Jersey State Police data on motorist stops, searches, and arrests conducted during the mid to late $1990 \mathrm{~s}^{69}$ This includes data on more than 87,000 police stops along the New Jersey Turnpike. ${ }^{70}$ The study reports that Whites comprised $59.4 \%$ of the drivers who were stopped, while Blacks and Hispanics only comprised $27 \%$ and $6.9 \%$ of the motorists who were stopped, respectively. ${ }^{71}$ The racial breakdown of those 1,193 motorists who consented to a vehicle search reveals a different picture; $53 \%$ were African American, $21 \%$ were White, and $24 \%$ were Hispanic. ${ }^{72}$ This racial disproportionality continued from 1996 through 1998 when approximately 3,000 of the vehicles stopped ended in arrest. In those stops, $62 \%$ of the motorists were Black and $32 \%$ were White. ${ }^{73}$

The New Jersey Attorney General's Interim report concluded that the New Jersey State Police used race as a factor in

65. Plaintiffs' Fourth Monitoring Report: Pedestrian and Car Stop Audit, Philadelphia Office of the American Civil Liberties Union, July 1998. [hereinafter Philadelphia ACLU report]. The study also includes data and analyses of street stops. Since the pedestrian cases do not entail a motorist stop, they are not part of the analysis herein. For discussion of which activity falls within the definition of racial profiling. See supra notes 12-13.

66. See id. at 1.

67. See id. at 8-17.

68. Id.

69. See New Jersey Department of Law and Public Safety, Interim Report of the State Police Review Team Regarding Allegations of Racial Profiling, http://www.state.nj.us/lps/intm-419.pdf. (Apr. 1999).

70. Id. at 26. Based on data from two locations, Cranbury and Moorestown between April 1997 and November 1998 (Data for February 1998 is missing.).

71. Id.

72. Id. at 27.

73. See id. at 29. 
determining whether to make a vehicle stop. ${ }^{74}$ Further, a small group of officers engaged in willful misconduct. ${ }^{75}$ Moreover, police officers as a group are influenced by negative stereotypes of minorities and this in turn affects their law enforcement practices. ${ }^{76}$

The above four studies comprise the core of research on racial profiling. They indicate that Black motorists are more likely to be stopped than someone of another racial group. The studies conclude that the stop rate for Black motorists is not explained by legally-relevant variables. However, there are notable gaps in the research designs and analyses. Based upon this legislative and empirical back drop, the following section charts a road map for future data collection and research.

\section{NEED TO KNOW, NEED TO DO: DEVELOPING A RESEARCH ROADMAP FOR RACIAL PROFILING}

The last several years have brought about great movement on the issue and problem of racial profiling. On all fronts, however, much more should be done. Below are the sketches of a racial profiling legislative and research roadmap. These directions, drawn directly from what we now know about ra-

74. The Report consists of searches conducted in Cranbury from January 1994 through March 1994; January 1996; March 1996; April 1997 through February 1999. It also includes Moorestown searches from January 1994 through April 1994; December 1994; January 1996; March 1996 through December 1996; and April 1997 through February 1999. Racial profiling is defined as "any action taken by a state trooper during a traffic stop that is based upon racial or ethnic stereotypes and that has the effect of treating minority motorists differently than non-minority motorists." Id. at 5 .

75. Id. at 7. Beyond a finding of racial disproportionality, the Attorney General's office also found that some New Jersey State Troopers were intentionally falsifying data on their vehicle stop reports. See id. at 25. "The review found that some officers engaged in racial profiling against minority motorists, and to obscure their practices, these officers logged data gathered on White motorists for their written reports. In April 1999, indictments were issued against two members of the New Jersey State Police for falsifying records and conducting illegal searches. See, e.g., David Kocieniewski, Trenton Charges 2 Troopers with Falsifying Drivers' Race, N.Y. TIMEs, Apr. 20, 1999 , at B1.

76. See supra note 70 , at 7 . 
cial profiling, address voids in our current knowledge base. Hopefully, if followed, this plan of action will move the social problem of racial profiling a step closer toward resolution.

EMPIRICAL ANALYsis A small amount of empirical research has been done on racial profiling. The existing research clearly clemonstrates that Blacks are disproportionately more likely to be subjected to a vehicle stop by the police-far in excess of their representation in the motorist population. ${ }^{77}$ There are, however, legitimate questions as to how explanatory these data are in understanding racial profiling. Additionally, there are reasonable concerns as to other independent variables that should be included in future studies.

The Government Accounting Office (GAO), in its review of the racial profiling literature, cites three problems with the existing research. ${ }^{78}$ First, the need to determine whether there are race-based differences in the "severity of traffic violations."79 For example, whether African-Americans who exceed the speed limit are more likely to exceed it by, say, 20 miles, compared with Whites who are likely to exceed it by 10 miles. There is no reason or data to indicate that such racial differences exist. ${ }^{80}$ However, as the GAO Report suggests, if there were, it might explain, to some degree, the racial variability in motorist stops. ${ }^{81}$

Second, a consideration of whether there are race-based differences in the type of vehicle code violations. ${ }^{82}$ For example, are Blacks more likely to exceed the speed limit rather than have expired registration tags? Tied to this, are the police more likely to stop someone who is speeding, as opposed to someone who has an expired registration tag? This is impor-

77. U.S. Gen. Acct. Off., Racial Profiling, GGD-00-41, at 1 (2000). The GAO report consists of data collected from August 1999 through February 2000 and is based primarily on data collected in California police departments, specifically; San Diego, San Jose, Alameda, and Piedmont. Id. at 7.

78. GA.O Report on Racial Profiling, supra note 33, at 1.

79. Id. at 7.

80. See id. at 2.

81. See id. at 26, 28-29, 34.

82. See id. at 7 . 
tant information to factor into an analysis of the role of race in motorist stops. ${ }^{83}$

Third, the GAO Report raises design and validity questions about the existing research. One of these concerns is the use of comparable time periods for the analyses. For example, ensuring that there is a match between the data gathered on the racial make-up of a police district and the racial composition of motorist stops. ${ }^{84}$ Also, there is the standard research problem of incomplete data. ${ }^{85}$ For example, in some of the racial profiling analyses there is information missing from a large number of the cases. ${ }^{86}$

The research limitations discussed in the GAO Report suggest that the analyses of additional variables might explain why Black motorists experience such a high vehicle stop rate. Moreover, there are other variables which, if considered, might indicate that Blacks are without empirical justificationat a greater risk of being stopped. David Harris' research on racial profiling in Ohio (Toledo, Akron, and Columbus) is relevant as his research identifies two such variables. ${ }^{87}$ The first variable considers the frequency of travel by race. Harris cites figures from the Federal Highway Administration (FHA) which indicate that on average Whites make 4.4 vehicles trips daily, while Blacks average 3.9 per day. ${ }^{88}$ The second variable considers the ownership of vehicles by race. The FHA data indicate that $21 \%$ of Black households do not own a vehicle. ${ }^{89}$ Both of these factors are critical to the measurement of racial

83. This raises other issues as well. For example, whether the number of vehicle code violations influences an officer's decision to pull over a motorist.

84. See id. at 32.

85. See id. at 2.

86. For example, in the Philadelphia Study, race data for most of the motorists was not available. See supra note 33, at 10. "The race of the driver was not recorded for about half of the approximately 1,500 police stops made during the two weeks." Id.

87. See, David Harris, The Stories, the Statistics, and the Law: Why "Driving While Black" Matters, 84 MNN. L. Rev. 265 (1999).

88. Id. at 285 n.101.

89. Id. at 285. 
profiling because they affect the likelihood that Blacks will be stopped by the police. ${ }^{90}$

Beyond conducting more sophisticated quantitative analyses of racial profiling, future research should offer a well-developed theoretical framework. The empirical studies have offered little in the way of theoretical scaffolding for analyses of racial targeting. As the above discussion makes clear, racial profiling raises both legal and sociological issues. Rigorous analysis of racial profiling as a social problem requires that researchers engage in theoretical analysis as well. ${ }^{91}$

Legislative EnActment The Traffic Stops Statistics Study Act of 1999 represents a major step forward in analyzing racial profiling. ${ }^{92}$ The Act would require police officers to: note the alleged traffic violation; identify the race, gender, ethnicity, and age of the driver; report whether they searched the vehicle, and if so, did they find any contraband. ${ }^{93}$ The full weight of its impact cannot be known, however, until it is passed. As drafted, the bill has several notable problem spots which skew the picture of racial targeting practices. First, the bill does not mandate data collection on the race of the officer. As commentators have observed, this information might be useful in understanding the locus of the racial profiling problem. ${ }^{94}$ Understandably, police officers do not want to be singled out and identified as racial profilers. Of course, profiling by its nature, singles out and identifies individuals. Given this, it appears odd that attempts at identifying those who engage in the practice are met with a closed door..$^{95}$

90. See id. at 281-88 (discussing the likelihood ratios related to race and traffic stops in Ohio).

91. Theoretical approaches to understanding police behavior, police departments, and legal jurisprudence related to racial profiling, can draw from an array of disciplines, including psychology, sociology, and political science.

92. H.R. 1443, 106th Cong. \& 1 (1999).

93. $I d$. at $\S 2$.

94. See, e.g., supra note 33.

95. The Bill prohibits the release of information that would "reveal the identity of any individual who is stopped or any law enforcement officer involved in a traffic stop". H.R. 1443, 106th Cong. $§ 4$ (1999). Data on officers' race, however, can be collected without identifying officers by name. 
Second, the bill does not require state-level reporting. As designed, it would provide national level data. ${ }^{96}$ It is not clear, however, whether state level (or regional) analysis could be culled from these statistics. Nonetheless, the more detailed the portrait, the greater the likelihood that workable solutions can be adopted and implemented to combat racial profiling.

OUTSTANDING IsSUES AND CONCERNS There are other important racial profiling issues beyond those directly raised by the existing research and pending legislation. First, how is "race" operationalized? Racial profiling analyses need to be stretched beyond the staid Black/White dichotomy. Studies should include Hispanics, Asian Americans, and American Indians. There is a growing body of evidence that Hispanics, American Indians, and Asian Americans also experience racial profiling. ${ }^{97}$ American Indians offer an interesting case in point. In its 1999 report, "American Indians and Crime," the Department of Justice reports that the American Indian arrest rate for alcohol-related offenses (e.g., driving under the influence and public drunkenness), is more than two times the national average. 98 This fact raises the issue of whether the rate for American Indians is partly attributable to racial profiling by law enforcement.

Second, there is an undercurrent in the debate on racial profiling that divides the issue into two camps. On the one hand, one school of thought is that Blacks are disproportionately subject to vehicle stops because Blacks are disproportionately engaged in criminal activity. On the other hand, there are those who believe that Blacks are stopped because the police engage in racially-discriminatory practices. ${ }^{99}$ The differentia-

96. The bill directs the Attorney General to collect traffic stop data, "from a nationwide sample of jurisdictions." Id. at $\S 2$.

97. See supra note 13.

98. U.S. Dep't of Just., American Indians and Crime, at 5-6 (1999), available at http://www.ojp.usdoj.gov/bjs/pub/ascii/aic.txt. According to the findings, per 100,000 people in the population, American Indians have an arrest rate (alcohol related offenses) of 2,550 , which compares with the national rate of 1,064 . Id.

99. This is a strain of the standard criminological disparity versus discrimination debate. See, e.g., Russell, supra note 7, at 30. "[R] esearch shows evidence of racial discrimination against Blacks in the criminal justice system 
tion into two schools of thought is a useless dichotomy since both phenomena can co-exist. Indeed, Blacks can be disproportionately involved in crime and at the same time the police can engage in racially-motivated traffic stops.

Third, there is a class-based tinge to the discussions of racial profiling. The fact that so many well-known African-American men have shared their profiling experiences has sensitized the general public to the problem. ${ }^{100}$ The Black, middle-class, professional male, has become the poster child for racial profiling. One downside of this class-skewed discussion, however, has been the tacit implication that those Blacks who do not fall into the "Black professional" category may deserve to be profiled: profiling is acceptable so long as it does not sweep the "good Blacks" within its net. This middle-class standard of analysis mutes the obvious truth that racial profiling is an objectionable practice. This is true regardless of the descriptive statistics of those who are subjected to the practice. Thus, racial profiling is problematic whether it is used against Denzel Washington or against the stereotypical "boy in the hood." A class-driven dialogue on racial targeting undercuts the civil rights of those people most likely to be subject to profiling low-income, poorly educated, young, Black men, living in urban areas.

\section{CONCLUSION}

In many ways, the problem of racial profiling operates as a razor-sharp proxy for the larger goal of racial justice. Racial profiling lies at the intersection of historical truths about race, crime, law, state action, and civil rights. As a consequence, modest measures taken to address the problem have the potential for large social gain. In particular, the centuries-old tension between police and minority communities may im-

and evidence that Blacks disproportionately offend." Brian MacLean and Dragan Milovanovic, Racism, Empiricism and Criminal Justice 1-24 (1990) (providing an overview of the longstanding dispute over whether and to what degree there is racial discrimination within the U.S. criminal justice system).

100. See supra notes 8, 23. 
prove. The above discussion has offered some strategies for fine-tuning future assessments and analyses of racial profiling. 
HeinOnline -- 3 Rutgers Race \& L. Rev. 822001 